Review Article

\title{
COSMECEUTICAL IMPORTANCE OF FERMENTED PLANT EXTRACTS: A SHORT REVIEW
}

\author{
BHAGAVATHI SUNDARAM SIVAMARUTHI, CHAIYAVAT CHAIYASUT, PERIYANAINA KESIKA*
}

Innovation Center for Holistic Health, Nutraceuticals, and Cosmeceuticals, Faculty of Pharmacy, Chiang Mai University, Chiang Mai 50200, Thailand

Email: p.kesika@gmail.com

Received: 30 Mar 2018, Revised and Accepted: 24 May 2018

\begin{abstract}
Personal care products, especially cosmetics, are regularly used all over the world. The used cosmetics are discharged continuously into the environment that affects the ecosystem and human well-being. The chemical and synthetic active compounds in the cosmetics cause some severe allergies and unwanted side effects to the customers. Currently, many customers are aware of the product composition, and they are stringent in product selection. So, cosmetic producers are keen to search for an alternative, and natural active principles for the development and improvisation of the cosmetic products to attain many customers. Phytochemicals are known for several pharmacological and cosmeceutical applications. Fermentation process improved the quality of the active phytochemicals and also facilitates the easy absorption of them by human system. Recently, several research groups are working on the cosmeceutical importance of fermented plant extracts (FPE), particularly on anti-ageing, anti-wrinkle, and whitening property of FPE. The current manuscript is presenting a brief on cosmeceutical importance of FPE.
\end{abstract}

Keywords: Fermented plant extracts, Cosmetics, Phytochemicals, Anti-aging, Anti-wrinkle

(C) 2018 The Authors. Published by Innovare Academic Sciences Pvt Ltd. This is an open access article under the CC BY license (http://creativecommons.org/licenses/by/4.0/) DOI: http://dx.doi.org/10.22159/ijap.2018v10i4.26355

\section{INTRODUCTION}

Fermented foods (FF), fermented plant beverages (FPB), and its extracts represent an essential role in the cultural development and foodscape of humans. The types and preparation of FF are fluctuating based on the origin of the food. The ethnobotanical survey, functional importance, and making process of traditional fermented plant foods of Northern Europe, Eastern Europe, Korea, India, and Namibia have been reported recently [1-5]. FPB and fermented plant extracts (FPE) are rich sources of antioxidants, vitamins, minerals, polyphenols, proteins, fibres, and probiotics. Therefore, FPB has been reported for several health benefits [6-8]. The improvement of phytochemical content and bioactivities of FPB depends on the fermenting microbes and fermentation conditions. It has already been reported that the enhancement of phyto-content and formation of desired micronutrients like L-glutamic and $\gamma$-aminobutyric acids in fermented plants are obtained with specific starter cultures [9-12].

Cosmetics are stable mixtures of one or more active compounds with additives and some preservatives, which offers the enhancement of the physical appearance of the users. Cosmetics usage and cosmetic industries are increasing in the modern world. The cosmetic industries are keen on the development of new products or improvement of existing products with innovative active principles. Recently, dynamic tenets from natural resources are eminent among the company as well as consumers. Terrestrial and marine resources are the commonlysearched source of active compounds and are reported for several cosmetic applications like anti-ageing, anti-wrinkle, skin whitening, and natural dyes [13]. In another hand, the release of cosmetic debris, and cosmetic discharges in the domestic sewage leads to serious concern about human health. Some cosmetic constituents like parabens and triclosan are considered as severe environmental pollutants [14]. Effective and safe alternatives for the development of future cosmetics is necessary. The food-based bioactive principles may provide a possible way to advance the cosmetic research and its market. Recently, scientific reports are revealing the potential of FPB and FPE in cosmetic fields.

We have searched the literature in Scopus, PubMed, Google Scholar using the keywords "Fermented Plant" and "Cosmetics". There was no year based restriction in selecting the publications. The literature that deals with the use of fermented plant juices and its extract for the cosmetic purposes were selected for the preparation of the current manuscript. The present study provides an overview of reported cosmeceutical importance of FPE in brief.

\section{Cosmeceutical Importance of FPE}

The aqueous extract of Fructus arctii was fermented with Grifola frondosa HB0071 (FFAE), and also $\beta$-glucosidase content, 5lipoxygenase inhibitory and antioxidant activities were analyzed. FFAE treated UV-A exposed human dermal fibroblasts show reduced expression of matrix metalloproteinase-1 (MMP-1), and the suppression was dose-dependent. The collagen biosynthetic activity was also stimulated by FFAE. The results suggested that FFAE can be a strong cosmetic candidate [15].

Bifidobacterium animalis mediated fermentation process increased the amino acids, sugars, proteins, peptides, and free isoflavonoids content of fermented soybean extract (FSBE) compared to fresh soybean, which may offer some cosmetological benefits like moisture, antiageing, emollience, and tensor action. Thus, facial mask formulation was prepared with FSBE, and the physical and physicochemical stability were assessed. The results suggested that the formulation with 5\% FSBE was stable in the measured parameters like performance test, $\mathrm{pH}$, apparent viscosity, and organoleptic characteristics that could be used as a safe facial mask [16].

Astragalus membranaceus var. mongholicus was fermented by Bacillus subtilis natto ATCC 7059 (FAME), and the functionality of fermented extract was studied using human epidermal keratinocytes and dermal fibroblasts (table 1). FAME had a growth-stimulating effect on keratinocytes and fibroblasts, and also significantly enhanced the production of hyaluronic acid (HA), one of the main extracellular matrix components in the skin. The expression of hyaluronan synthase 2 and 3 were upregulated by FAME in fibroblasts, and $\mathrm{HaCaT}$ cells in a dose-dependent manner, respectively. Even though fermentation reduced the phytochemical content, especially isoflavonoids of A. membranaceus, FAME activates the HA production in the studied skin cells. The results claimed that FAME has skincare properties [17].

Citrus unshiu peel aqueous extracts were fermented by Schizophyllum commune (S-CPE), and the fermentation facilitates the conversion of glycoside form of flavonoids into aglycones. UV-A exposed human dermal fibroblasts was treated with S-CPE and found that S-CPE reduced the expression of MMP-1 in a dosedependent way. The UV-A mediated increase in senescenceassociated $\beta$-galactosidase has been reversed up to $45 \%$ by S-CPE. The presence of hesperetin in S-CPE may be responsible for the collagen biosynthetic activity, and the study suggested that S-CPE can be a cosmetic constituent [18]. 
The selected eight Korean herbs (Atractylodes macrocephala, Angelica gigas, Broussonetia kazinoki, Glycyrrhiza glabra, Lithospermum officinale, Morus alba, Poria cocos, and Paeonia albiflora) mixture (2\% each) were extracted with water and fermented using Phellinus linteus. Tyrosinase and melanogenesis suppression activity of the extract were analyzed. The results revealed that the extract has melanin and tyrosinase inhibition activity (dose-dependent manner) in 3-isobutyl-1-methylxanthine stimulated B16F0 mouse melanoma cells. The extract activates phosphatidylinositol 3-kinase/Akt/glycogen synthase kinase-3beta signalling pathway and suppresses the microphthalmia-associated transcription factor. Thereby, the extract exhibits the antihyperpigmentation effects [19].

Lactobacillus brevis mediated fermented red ginseng (FRG) was found to be rich in ginsenoside metabolites, flavonoids, polyphenols and uronic acid than that of the unfermented red ginseng (RG). The tyrosinase and elastase inhibitory activities were increased in FRG when compared to RG. The skin irritation and sensitization test was conducted in Hartley strain guinea pigs and found that FRG (10\%) was non-irritating material and had only $20 \%$ of sensitizing property compared to RG. The study claimed that FRG had increased whitening and antiwrinkle efficacy, and reduced toxic effect than that of the RG [20]. Alcaligenes piechaudii CC-ESB2 mediated fermented Rhodiola rosea L. (AFR) and fermented Lonicera japonica Thunb. (AFL) showed higher antioxidant activity and total phenol content in vitro. The results demanded that AFR and AFL can be appropriate for food, drug, and cosmetic applications [21].

Aqueous extract of Camellia sinensis (black, green, and white tea extracts) (AECS) has been reported for anti-melanogenic activity. Black tea extract showed tyrosinase inhibitory effect in a dosedependent manner, and it was attributed to reducing tyrosinase protein levels and tyrosinase activity. The results suggested that AECS could be a skin-whitening agent [22].

The solvent (50\% ethanol, 95\% ethanol, 50\% ethyl acetate, and water) extracts of Prunus persica (L.) Batsch, Paeonia suffruticosa
Andr., and Asparagus cochinchinensis (Loureiro) Merrill. were subjected to Bifidobacterium bifidum mediated fermentation. The fermented extracts were assessed for cytotoxicity, phytochemical content, free radical scavenging property, and tyrosinase inhibition activity. The results showed that all the extracts were nontoxic, and $50 \%$ ethanol extract exhibits improved tyrosinase inhibition activities than other solvent extracts. Finally, the study suggested that $50 \%$ ethanol extract of fermented A. cochinchinensis was the most significant skin-whitening candidate with superior antioxidant credibility [23].

The protein-rich, inexpensive, and pretreated (fermentation and germination) cowpea protein was studied for the emulsifying property. The results proved that germinated cowpea protein could produce stable emulsions compared to fermented cowpea protein [24].

Saccharomyces cerevisiae mediated fermented black ginseng (FBG) has been reported for the anti-wrinkle activity in cultured human fibroblasts (HS68) and proved that FBG was noncytotoxic. FBG treatment increased the expression of type I procollagen and tissue inhibitor of metalloproteinase- 2 and reduced the expression of MMP-1, MMP-2, and MMP-9 in HS68 cells [25]. Lactobacillus rhamnosus GG mediated fermented Codonopsis lanceolata extract (FCLE) was assayed for cytotoxicity, tyrosinase, and $\alpha$-glucosidase inhibition properties. The results suggested that FCLE exhibits a lower cytotoxic effect on CCD986sk cells than non-fermented counterpart and inhibits tyrosinase and $\alpha$-glucosidase activity [26]. Kim et al. [26] appealed that FCLE may be used in skin-whitening cosmetic formulations.

Sirilun et al. [27] reported the cosmeceutical application of fermented clove, black galingale, betel, noni, green tea, and mangosteen juices containing $0.1-3.0 \%$ of peppermint oil. The mouthwash (MW) formulations were prepared, and the appearance, stability, and anti-microbial properties were analyzed. The results suggested that MW solution that contains fermented plant juices and $0.2 \%$ of peppermint oil exhibited high stability and effective antimicrobial potential with enhanced aroma and flavor [27].

Table 1: Cosmeceutical properties of fermented plant extracts

\begin{tabular}{llllll}
\hline Study material & $\begin{array}{l}\text { Microbes } \\
\text { involved }\end{array}$ & Study type & Results & Key findings & Ref. \\
\hline Fermented Fructus & Grifola frondosa & $\begin{array}{l}\text { In vitro } \\
\text { (Human dermal } \\
\text { arctii extract (FFAE) }\end{array}$ & HB0071 & $\begin{array}{l}\text { FFAE exhibited 5-lipoxygenase inhibitory and } \\
\text { antioxidant activities. FFAE inhibit the expression } \\
\text { of matrix metalloproteinase (MMP-1) in UV-A }\end{array}$ & $\begin{array}{l}\text { Cosmetic } \\
\text { applications }\end{array}$
\end{tabular}
treated human fibroblasts (HDF) in a dosedependent manner.

Fermented soybean Bifidobacterium In vitro extract (FSBE) animalis

Bacillus subtilis In vitro natto (Human Fermented Astragalus mongholicus extract (FAME)

Aqueous extract of fermented Citrus unshiu peel extract (S-CPE)

Aqueous extract of
fermented eight
herbs

Schizophyllum commune linteus herbs epidermal keratinocytes and dermal fibroblasts) In vitro (Human dermal fibroblasts; HDFs)

In vitro (B16F0 mouse melanoma Cells)
Formulations were assessed for the stability at various physical conditions
Facial mask formulation containing 5\% FSBE was stable in organoleptic characteristics. Skincare

FAME inic acid production was stimulated by dermal fibroblasts. The expression of hyaluronan synthase 2 and 3 was increased after FAME exposure.

MMP-1 expression was inhibited, and level of senescence-associated $\beta$-galactosidase was decreased in S-CPE treated UV-A exposed HDFs. Hesperetin of S-CPE induces the collagen biosynthesis in fibroblasts.

Dose-dependent melanin and tyrosinase inhibition activity were observed in 3-isobutyl-1methylxanthine treated B16F0 mouse melanoma cells. The extract activates phosphatidylinositol 3kinase/Akt/glycogen synthase kinase-3beta signalling pathway and suppresses the microphthalmia-associated transcription factor. Fermentation process increased the ginsenoside metabolites in ginseng. The efficacy of whitening
S-CPE have UV-A

induced anti-

photoaging

property

Anti-

hyperpigmentation activity

Whitening, and antiwrinkle activity 


\begin{tabular}{|c|c|c|c|c|c|}
\hline & & $\begin{array}{l}\text { (Hartley strain } \\
\text { guinea pigs) }\end{array}$ & $\begin{array}{l}\text { and antiwrinkle was improved, and skin irritation } \\
\text { was reduced. }\end{array}$ & & \\
\hline $\begin{array}{l}\text { Fermented Rhodiola } \\
\text { rosea } \text { L. (AFR) and } \\
\text { Lonicera japonica } \\
\text { Thunb. (AFL) }\end{array}$ & $\begin{array}{l}\text { Alcaligenes } \\
\text { piechaudii CC- } \\
\text { ESB2 }\end{array}$ & In vitro & $\begin{array}{l}\text { Antioxidant capacity was also increased after } \\
\text { fermentation. }\end{array}$ & $\begin{array}{l}\text { Cosmetic } \\
\text { applications }\end{array}$ & [21] \\
\hline $\begin{array}{l}\text { Aqueous extract of } \\
\text { Camellia sinensis } \\
\text { (AECS) }\end{array}$ & - & $\begin{array}{l}\text { In vitro (Melan-A } \\
\text { cells) }\end{array}$ & $\begin{array}{l}\text { AECS inhibit the melanin } \\
\text { accumulation and synthesis, and tyrosinase activity. }\end{array}$ & Anti-melanogenic & [22] \\
\hline $\begin{array}{l}\text { Fermented walnut, } \\
\text { Moutan Cortex } \\
\text { Radicis, and } \\
\text { asparagus root } \\
\text { extracts }\end{array}$ & $\begin{array}{l}\text { Bifidobacterium } \\
\text { bifidum }\end{array}$ & $\begin{array}{l}\text { In vitro } \\
\text { (Skin fibroblast } \\
\text { cells, and murine } \\
\text { melanoma cells) }\end{array}$ & $\begin{array}{l}\text { Fermented herb extract showed high tyrosinase } \\
\text { inhibition activity than that of non-fermented } \\
\text { counterparts. The extracts were noncytotoxic. }\end{array}$ & $\begin{array}{l}\text { Skin-whitening } \\
\text { agent }\end{array}$ & [23] \\
\hline $\begin{array}{l}\text { Naturally fermented } \\
\text { cowpea, and } \\
\text { germinated cowpea }\end{array}$ & Natural & In vitro & $\begin{array}{l}\text { The germinated cowpea produced stable emulsions } \\
\text { better than that of fermented cowpea. }\end{array}$ & $\begin{array}{l}\text { Emulsifying } \\
\text { properties }\end{array}$ & [24] \\
\hline $\begin{array}{l}\text { Fermented black } \\
\text { ginseng (FBG) }\end{array}$ & $\begin{array}{l}\text { Saccharomyces } \\
\text { cerevisiae }\end{array}$ & $\begin{array}{l}\text { In vitro } \\
\text { (Human } \\
\text { fibroblasts HS68) }\end{array}$ & $\begin{array}{l}\text { Type I procollagen and tissue inhibitor of } \\
\text { metalloproteinase- } 2 \text { expressions were increased. } \\
\text { MMP-1, MMP- } 2 \text { and MMP-9 expression was } \\
\text { reduced by FBG }\end{array}$ & Anti-wrinkle & [25] \\
\hline $\begin{array}{l}\text { Fermented } \\
\text { Codonopsis lanceolata } \\
\text { extract (FCLE) }\end{array}$ & $\begin{array}{l}\text { Lactobacillus } \\
\text { rhamnosus GG }\end{array}$ & $\begin{array}{l}\text { In vitro } \\
\text { (CCD986sk cells) }\end{array}$ & $\begin{array}{l}\text { FCLE inhibits the tyrosinase and } \alpha \text {-glucosidase } \\
\text { activities and exhibits higher biological activity } \\
\text { than that of non-fermented } C \text {. lanceolata. }\end{array}$ & $\begin{array}{l}\text { Skin-whitening } \\
\text { agent }\end{array}$ & [26] \\
\hline $\begin{array}{l}\text { Fermented clove, } \\
\text { black galingale, betel, } \\
\text { noni, green tea, and } \\
\text { mangosteen juice }\end{array}$ & $\begin{array}{l}\text { Lactobacillus } \\
\text { plantarum }\end{array}$ & In vitro & $\begin{array}{l}\text { Fermented plant-herbal juices with } 0.2 \% \text { of } \\
\text { peppermint were found as an organoleptically } \\
\text { optimum formula for mouthwash. } \\
\text { Mouthwash formula with black galingale was stable } \\
\text { formulation with antimicrobial activity. }\end{array}$ & $\begin{array}{l}\text { Mouthwash } \\
\text { solution }\end{array}$ & [27] \\
\hline
\end{tabular}

\section{CONCLUSION AND FUTURE PROSPECTUS}

The cosmetic world is often changing their cosmetic formulations to improve the products' quality and acquire new customers. The use of cosmetics is growing among the Asian countries, and people are more aware of their product selection and to know about the ingredients of the products to secure them from toxic chemicals. So cosmetic companies and researchers are in an urge to screen the natural products for the possible cosmetic applications. It is known that fermentation process might improve the phytochemical content and its effective absorption. Thus, fermented natural extracts, especially non-animal based plant extracts, are mostly studied. Even though several scientific reports on the cosmeceutical importance of fermented plant extracts are available, the reported clinical studies and human trails do not sufficiently support the stated beneficial effects. Further detailed study on the molecular mechanism of cosmeceutical properties of fermented plant extracts is required. FPE may be the possible hope for the sustainable development of cosmetic products with consumers' and environmental protection.

\section{ACKNOWLEDGEMENT}

The authors gratefully acknowledge the Faculty of Pharmacy and Chiang Mai University, Chiang Mai, Thailand. Dr. Periyanaina Kesika (Ref: No. 6592(11)/588-77, dated 26 January 2018), and Dr. Bhagavathi Sundaram Sivamaruthi (Ref: No. 6592(11)/1379, dated 26 February 2018) wish to acknowledge the CMU Post-Doctoral Fellowship Chiang Mai University, Chiang Mai, Thailand.

\section{AUTHORS CONTRIBUTIONS}

Periyanaina Kesika and Bhagavathi Sundaram Sivamaruthi contributed to conception and design, acquisition, manuscript preparation, and critical revision of the manuscript. Chaiyavat Chaiyasut involved in the review and finalization of the manuscript. All the authors agree with the content of the manuscript.

\section{CONFLICTS OF INTERESTS}

All authors declared that there is no conflict of interest.

\section{REFERENCES}

1. Skara T, Axelsson L, Stefansson G, Ekstrand B, Hagen H. Fermented and ripened fish products in the Northern European countries. J Ethn Foods 2015;2:18-24.
2. Soukand R, Pieroni A, Biro M, Denes A, Dogan Y, Hajdari A, et al. An ethnobotanical perspective on traditional fermented plant foods and beverages in Eastern Europe. J Ethnopharmacol 2015;170:284-96.

3. Shin D, Jeong D. Korean traditional fermented soybean products: Jang. J Ethn Foods 2015;2:2-7.

4. Ray M, Ghosh K, Singh S, Mondal KC. Folk to functional: An explorative overview of rice-based fermented foods and beverages in India. J Ethn Foods 2016;3:5-18.

5. Misihairabgwi J, Cheikhyoussef A. Traditional fermented foods and beverages of Namibia. J Ethn Foods 2017;4:145-53.

6. Corbo MR, Bevilacqua A, Petruzzi L, Casanova FP, Sinigaglia M. Functional beverages: the emerging side of functional foodscommercial trends, research, and health implications. Compr Rev Food Sci Food Saf 2014;13:1192-206.

7. Marsha AJ, Hill C, Ross RP, Cotter PD. Fermented beverages with health-promoting potential: Past and future perspectives. Trends Food Sci Technol 2014;38:113-24.

8. Marco ML, Heeney D, Binda S, Cifelli CJ, Cotter PD, Foligne B. Health benefits of fermented foods: microbiota and beyond. Curr Opin Biotechnol 2017;44:94-102.

9. Woraharn S, Lailerd N, Sivamaruthi BS, Wangcharoen W, Sirisattha $\mathrm{S}$, Chaiyasut C. Screening and kinetics of glutaminase and glutamate decarboxylase producing lactic acid bacteria from fermented Thai foods. Food Sci Technol Campinas 2014;34:793-9.

10. Woraharn S, Lailerd N, Sivamaruthi BS, Wangcharoen W, Peerajan S, Sirisattha S, et al. Development of fermented Hericium erinaceus juice with a high content of L-glutamine and L-glutamic acid. Int J Food Sci Technol 2015;50:2104-12.

11. Woraharn S, Lailerd N, Sivamaruthi BS, Wangcharoen W, Sirisattha S, Peerajan S, et al. Evaluation of factors that influence the L-glutamic and g-aminobutyric acid production during Hericium erinaceus fermentation by lactic acid bacteria. Cyta J Food 2016;14:47-54.

12. Peerajan S, Chaiyasut C, Sirilun S, Chaiyasut K, Kesika P, Sivamaruthi BS. Enrichment of nutritional value of Phyllanthus emblica fruit juice using the probiotic bacterium, Lactobacillus paracasei HII01 mediated fermentation. Food Sci Technol Campinas 2016;36:116-23.

13. Guillerme J, Couteau C, Coiffard L. Applications for marine resources in cosmetics. Cosmetics 2017;4:35.

14. Juliano C, Magrini GA. Cosmetic ingredients as emerging pollutants of environmental and health concern. A mini-review. Cosmetics 2017;4:11. 
15. Kim J, Bae J, Song M, Lee G, Choe S, Pyo H. Biological activities of Fructus arctii fermented with the basidiomycete Grifola frondosa. Arch Pharm Res 2010;33:1943-51.

16. Vieira RP, Fernandes AR, Kaneko TM, Consiglieri VO, Pinto CASO, Pereira CSC, et al. Physical and physicochemical stability evaluation of cosmetic formulations containing soybean extract fermented by Bifidobacterium animalis. Braz J Pharm Sci 2009;45:515-25.

17. Hsu M, Chiang B. Stimulating effects of Bacillus subtilis nattofermented Radix astragali on hyaluronic acid production in human skin cells. J Ethnopharmacol 2009;125:474-81.

18. Bae JT, Ko HJ, Kim GB, Pyo HB, Lee GS. Protective effects of fermented Citrus unshiu peel extract against ultraviolet-ainduced photoageing in human dermal fibroblasts. Phytother Res 2012;26:1851-6.

19. Cha J, Yang H, Moon H, Cho Y. Inhibitory effect and mechanism on melanogenesis from the fermented herbal composition for medical or food uses. Food Res Int 2012;45:225-31.

20. Lee H, Kim M, Park Y, Park HJ, Chang UJ, Kim SY, et al. Fermenting red ginseng enhances its safety and efficacy as a novel skin care anti-ageing ingredient: in vitro and animal study. J Med Food 2012;15:1015-23.

21. Chen Y, Liou H, Chan C. Tyrosinase inhibitory effect and antioxidative activities of fermented and ethanol extracts of
Rhodiola rosea and Lonicera japonica. Sci World J 2013. http://dx.doi.org/10.1155/2013/612739.

22. Kim YC, Choi SY, Park EY. Anti-melanogenic effects of black, green, and white tea extracts on immortalized melanocytes. J Vet Sci 2015;16:135-43.

23. Wang G, Chen C, Lin C, Huang C, Lin C, Cheng C, et al. Tyrosinase inhibitory and antioxidant activities of three Bifidobacterium bifidum-fermented herb extracts. Ind Crops Prod 2016;89:37682.

24. Imbart S, Regnault S, Bernard C. Effects of germination and fermentation on the emulsifying properties of cowpea (Vigna unguiculata L. Walp.) proteins. Food Meas 2016;10:119-26.

25. Pham QL, Jang HJ, Kim KB. Anti-wrinkle effect of fermented black ginseng on human fibroblasts. Int J Mol Med 2017;39:681-6

26. Kim SS, Jeong MH, Choi WY, Seo YC, Ahn J, Yoon WB, et al. Inhibitory effects of fermented Codonopsis lanceolata on tyrosinase and $\alpha$-glucosidase activities. World Acad Sci Eng Technol 2010;65:446.

27. Sirilun S, Sivamaruthi BS, Kumar N, Kesika P, Peerajan S, Chaiyasut C. Lactobacillus-fermented plant juice as a potential ingredient in cosmetics: Formulation and assessment of natural mouthwash. Asian J Pharm Clin Res 2016;9(Suppl 3):52-6. 